\title{
Influence of Motivation, Communication and Work Culture on the Performance of Agricultural Extension in Parepare
}

\author{
Muhammad Siri Dangnga \\ Muhammadiyah University of \\ Parepare \\ muhammad.siri@gmail.com
}

\author{
Andi Nuddin \\ Muhammadiyah University of \\ Parepare \\ muhammad.siri@gmail.com
}

Irninthya Nanda Pratami Irwan
Muhammadiyah University of
Parepare
irninthyanandapratami@gmail.com

Buhaerah

Institut Agama Islam Negeri Parepare, Indonesia

buhaerahstain@gmail.com

\begin{abstract}
Agricultural counselling as an education for farmers should be used for the foundation of the work philosophy to increase the potential and ability of the farmers without depending on others. The results of this activity are farmers can be independent and be able to develop their agriculture business. This study aims to determine the influence of motivation, communication and work culture on the performance of agricultural counselling in Parepare City. This study was conducted in June-August 2017; techniques of collecting data used were interview, literature study, documentation, and questionnaire. Data analysis technique used multiple regression analysis through the Statistical Product and Service Solution (SPSS) 24. The result of this study indicated that motivation, communication, and work culture both partially and simultaneously have a positive and significant influence to the performance of agricultural counselling in Parepare City and motivation variable has the most dominant influence among the three independent variables of this research.
\end{abstract}

Keywords: agricultural extension, motivation, communication, work culture, performance

\section{INTRODUCTION}

The role of the agricultural sector in the national economy is very important and strategic. This is mainly because the agricultural sector still provides jobs for most of the rural people and provides food for the people across country. The urge to meet the food needs of the growing population made the Indonesian people try to increase their food production [1]. Agricultural extension in Indonesia has a long history, beginning in the early of $20^{\text {th }}$ century. The agricultural extension begins with the need to improve agricultural products, both for the interests of the colonists and to meet the needs of indigenous. After reaching independence, extension efforts continue to be developed by the government. Various agricultural facilities and infrastructure are provided; the number of agriculture extension workers is increased and enhanced. If the agriculture extension firstly emphasized the guidance to the farmers in good farming, it has turned into pressure on technology transfer, which is to enable farmers to increase their productivity and production [2].

According to the Ministry of Agriculture (2014), the problems of agricultural development in Indonesia include problems of agricultural land, infrastructure, seeds, regulation or institutional, capital and human resources. One of the problems in terms of human resources is the limitations of agricultural extension workers both in terms of quantity and quality. Therefore, the direction of agricultural development policy of 2015-2019 formulated to overcome these problems. According to the Minister of Agriculture (Regulation No. 91 series 2013), to build the qualified and reliable agricultural of human resources, professional, creative, innovative, and insightful agricultural extension performance are necessary that agricultural extension can be carried out productively, effectively and efficiently [3].

In order to maximize the extension function, the components in extension institution play very important roles. One of the components of extension institution is agriculture extension as human resources development in empowering farmers. The success of agricultural extension can be seen from the change of farmer's knowledge which is better than before. Agricultural extensions should be able to build good cooperation with farmers, and farmers should develop a sense of trust in agriculture extension workers so that farmers are expected to utilize information, introduction of new technologies and knowledge provided by agriculture extension workers. To be able to run the program effectively and efficiently, the agriculture extensions need a strong motivation so that they have the kind of impetus to be able to exert their ability in carrying out their duties as counselors. Besides, communication also plays an important role in the implementation of the tasks of agriculture extensions workers, both communication between agriculture extension workers and farmers and communication between fellow agriculture extensions. Another important thing is related to the work culture applied by the agriculture extension workers in their daily life, work culture is a person's perspective or the way someone gives meaning to the work [4]-[5]. 
These three things are expected to provide positive feedback on the implementation of the tasks of extension workers; in addition, the most important is the increased performance of agricultural extension workers in the achievement of the implementation of all programs or materials presented for the farmers [6]. Parepare is a city in the province of South Sulawesi, Indonesia. The city has an area of $99.33 \mathrm{~km} 2$, covering 4 sub-districts (Bacukiki, Bacukiki Barat, Ujung, and Soreang) and has a population of 138,699 inhabitants. Although Parepare is not the center of agricultural products in South Sulawesi, it does not mean that Parepare does not have the land used for agricultural land. Based on the type of irrigation, the majority of paddy fields in Parepare City are rained lowland rice with the widest area in Bacukiki Sub-district reaching 372 hectares of total rained field 594 hectares. As for types of rice fields with technical irrigation is only available in Bacukiki District area of 240 hectares. Commodities presented in the food crop sub-sector include paddy rice, paddy fields, corn, peanuts, green beans, cassava, and sweet potatoes. Of all these commodities, rice paddy is a commodity with the highest production of 5,410 tons, the next is the corn commodity of 4,776 tons [7]-[8].

The research objectives that are achieved in the implementation of this research are: 1) to know the significant influence of motivation, communication and work culture simultaneously to the performance of agricultural extension workers in Parepare City; 2) to know the significant influence of motivation, communication and work culture partially on the performance of agricultural extension workers in the City of Parepare. (3) to know the independent variables that have a dominant influence on the performance of agricultural extension workers in the City of Parepare

\section{METHOD}

This research was conducted at the Department of Agriculture, Marine, and Fisheries of Parepare City within 3 months (May 2017-July 2017). Population in this research is all agriculture extension workers with civil servant status in Parepare City which is under the Department of Agriculture, Marine and Fishery of Parepare City, which amounts to 31 people. Sampling technique in this research is using saturated sampling technique where all members of the population (agricultural extension) in Parepare City become sample of research.

Table 1 Result of Multiple Linear Regression Analysis

\begin{tabular}{lccc}
\hline \multicolumn{1}{c}{ Variable } & $\begin{array}{c}\text { Regression } \\
\text { Coefficient }\end{array}$ & $\mathrm{t}$ & sig \\
\hline (Constant) & 3,142 & 0,077 & 0,003 \\
\hline Motivation & 0,770 & 3,813 & 0,001 \\
\hline Communication & 0,430 & 2,790 & 0,001 \\
\hline Work Culture & 0,234 & 2,218 & 0,001 \\
\hline
\end{tabular}

Source: Result of SPSS Processing Year of 2017, Version 24
Based on Table 1, it can be obtained the following regression formula:

$$
\mathrm{Y}=3,142+0,770 \mathrm{X} 1+0,439 \mathrm{X} 2+0,234 \mathrm{X} 3 \text { Or }
$$

Performance $=3,142+0,770$ Motivation+ 0,439

Communication $+0,234$ Work Culture

Based on regression analysis above can be explained as follows:

The constant of 3,142 states is that the value of performance before influenced by motivation, communication and work culture factor is positive. Motivation variable (X1) has the positive effect on agriculture extension with the regression coefficient of 0,770 with the meaning that if the variable of motivation variable increase by one point, it can be predicted that the performance variable will increase by 0,770 . This is in accordance its performance. Communication Variable (X2) has a positive effect on an agricultural extension with a regression coefficient of 0.439 with the meaning that if communication variable increases by one point, it can be predicted that the performance variable will increase by 0,439 . The findings of this research are relevant to Marliati et al (2008: 98) which states that the competence of agricultural instructor in communicating has an effect on improving agricultural instructor performance.

Working Culture Variable (X3) has the positive effect to agricultural extension performance with regression coefficient equal to 0,234 with the meaning that if work culture variable rises by one point, it can be predicted that performance variable will increase by 0,234 . This is in accordance with research findings the relationship between work culture and extension performance showed a positive linear relationship. The higher the value of work culture, the higher the performance of agricultural instructor workers.

\section{A goodness of Fit Test}

The accuracy of the sample regression function in estimating the actual value can be assessed by its Goodness of Fit Test. Statistically; at least this can be measured from the value of a coefficient of determination, $\mathrm{F}$ statistical value and $\mathrm{t}$ statistical value.

\section{Partial Test (T-Test)}

The t-test is intended to know how far the influence of one independent variable (motivation, communication, and work culture) individually in explaining the dependent variable (extension performance).

Based on the data presented in Table 2, the following details can be made:

Motivation (X1) on Agriculture Instructor Performance (Y)

From the result of calculation by using SPSS obtained $\mathrm{t}$ count equal to 3,813 and with $\mathrm{t}$ table equal to 2,051 , So $\mathrm{t}$ count $>t$ table. In addition, the probability value ( $p$-value) is 0.001 . The probability value is smaller than the alpha (5\%). Thus, it can be concluded that the motivation effect 
Table 2 Result of Partial Test (T Test)

\begin{tabular}{lllll}
\hline Independent Variable & $\mathrm{T}$ value count & $\mathrm{T}$ value table & Significant Value & Information \\
\hline Motivation $(X 1)$ & 3,813 & 2,051 & 0,001 & Significant \\
Communication $(X 2)$ & 2,790 & 2,051 & 0,001 & Significant \\
Work Culture $(X 3)$ & 2,218 & 2,051 & 0,002 & Significant \\
\hline
\end{tabular}

on the performance of agricultural extension in the city of Parepare. The findings of this study also in accordance with the findings which states that the partial or simultaneous motivation gives effect on the performance of agricultural instructor.

Communication (X2) on Agriculture Instructor Performance (Y) from the result of calculation by using SPSS obtained t count equal to 2,790 and with t table equal to 2,051 , so $t$ count $>\mathrm{t}$ table. In addition, the value of probability (p-value) is 0.001 , Value of the probability is less than the alpha (5\%). Thus, it can be concluded that the communication has an effect on the performance of agricultural instructor in the city of Parepare. This is in accordance with the results of the descriptive analysis of respondents who showed that there has been an established good communication between instructors to fellow instructors. This is supported by the statement Kusumawijaya (2016: 3) that communication is one key to success in extension activities.

Work Culture (X3) on Agriculture Instructor Performance (Y) from the result of calculation by using SPSS obtained t count equal to 2,218 and with t table equal to 2,051 , So $t$ count $>t$ table. In addition, the probability value (p-value) is 0.002 . The probability value is smaller than the alpha $(5 \%)$. Thus, it can be concluded that the motivation has an effect on the performance of agricultural instructor in city of Parepare. This is in accordance with the that the work culture either partially or simultaneously affects the performance of agricultural extension workers.

\section{Simultaneous Test (F Test)}

The simultaneous test $(\mathrm{F})$ is intended to show statistically the influence of collectively from the independent variable (Motivation, Communication, and Work Culture) on the research, to the performance of agricultural extension in Parepare City.

Table 3 Result of Simultaneous Test (F Test)

\section{Significant Value}

0,002

Simultaneous Test of X1, X2, X3 to Y, Data in table 3 obtained the value of $F$ count of 6.599 and with the value of probability (p-value) of $0.002, \mathrm{~F}$ value count $(6.599)>$ $\mathrm{F}$ table (2.96), and the value of significance $0.002<$ from 0.005 , therefore the research hypothesis states that "There is a positive and significant influence between Motivation,
Communication, and Work Culture simultaneously on the performance of agricultural instructor workers in Parepare City."

\section{Coefficient of Determination}

In addition to partial and simultaneous testing, then there is one more coefficient that has significance for the regression, the coefficient of determination (R2). The coefficient of determination explains how much influence of all independent variables to the dependent variable. The value of R2 can be seen in Table 14 .

Table 4 Result of Coefficient of Determination Test

\begin{tabular}{lll}
\hline $\mathrm{R}$ & $\mathrm{R}$ Square $\left(\mathrm{R}^{2}\right)$ & Adjusted R Square \\
\hline 0,747 & 0,558 & 0,544 \\
\hline
\end{tabular}

The calculation results using SPSS version 24 program can be seen that the coefficient of determination (R2) obtained for 0,558 . This means that $55.8 \%$ performance of agricultural extension of Parepare City can be explained by motivation, communication, and work culture variables, while the remaining $44.2 \%$ of agricultural instructor performance in Parepare City is influenced by other variables which are not examined in this research.

\section{CONCLUSION}

Based on the results of research and discussion in this study, the conclusions that can be taken are: 1) Simultaneously there is a positive and significant influence between motivation, communication and work culture on the performance of agricultural instructor workers in Parepare City; 2) Partially there is a positive and significant influence between the motivation, communication and work culture on the performance of agricultural instructor workers in the City of Parepare; 3) Motivation variable has a more dominant influence on agricultural extension performance in Parepare City compared with communication and work culture variables.

\section{REFERENCES}

[1] J. Farrington, "The changing public role in agricultural extension," Food Policy, 1995.

[2] B. Wicke, R. Sikkema, V. Dornburg, and A. Faaij, "Exploring land use changes and the role of palm oil production in Indonesia and Malaysia," Land 
use policy, 2011.

[3] P. Wicaksono, S. Sugiyanto, and M. Purnomo, "Faktor-Faktor yang Berkontribusi Terhadap Kinerja dan Kompetensi Penyuluh Pertanian Pada Jenjang Jabatan Penyuluh Pertanian Ahli (Kasus di Malang, Jawa Timur)," HABITAT, 2016.

[4] Z. Abdul Rashid, M. Sambasivan, and J. Johari, "The influence of corporate culture and organisational commitment on performance," $J$. Manag. Dev., 2003.

[5] A. A. Suharto, "Pengaruh Kualitas Sumber Daya Manusia, KOmitmen Dan MOtivasi Terhadap
Kinerja Pegawai Pada inspektorat kabupaten kediri," Ilmu Manaj., 2012.

[6] Y. Rapareni, "Analisis Pengaruh Kompetensi Komunikasi, Kecerdasan Emosional, Dan Budaya Organisasi Terhadap Kinerja Karyawan Radio Republik Indonesia Palembang," Univ. Diponegoro Semarang, 2013.

[7] W. Colquitt, Lepine, Manajemen kinerja. 2011.

[8] V. G. Anthony, "Sistem Pengendalian Manajemen," in Sistem Pengendalian Manajemen, 2002. 
